- Nama : Graise

- Nirim : 2020196524

- Kelas : D. Teologi

\title{
PERANAN PEREMPUAN DALAM PENDIDIKAN KRISTEN
}

Abstract; The role of women today is not something that is taboo to be discussed. This paper contains studies on women, feminism, the essential similarities of men and women, theological views on women, and their role in Christian religious education. The method used in this research is qualitative research. Who intends to understand a phenomenon experienced by the research subject, for example behavior, perception, motivation, action, etc, holistically in the church. And women who have a background in Christian Religious Education can play a role in the church as Christian Religious Education pastors, teachers, deacons, members in Christian Religious Education bodies or commissions, and Sunday School teachers. The knowledge of Christian Religious Education possessed by women is a gift from God, which should be developed and practiced in the church.

Keywords: Women, Church Christian Religious Education

\begin{abstract}
Abstrak; Peran perempuan pada masa kini bukanlah sesuatu yang tabu untuk diperbincangkan. Tulisan ini memuat kajian tentang perempuan, feminisme, kesamaan esensial laki-laki dan perempuan, pandangan teologis tentang perempuan, dan peranannya dalam pendidikan agama Kristen. Metode yang digunakan dalam penelitian ini adalah penelitian kualitatif. Yang bermaksud memahami suatu fenomena yang dialami oleh subjek penelitian misalnya perilaku, persepsi, motivasi, tindakan, dan lainlain, secara holistik di dalam gereja. Dan perempuan yang memiliki latar belakang Pendidikan Agama Kristen dapat berperan di dalam gereja sebagai pendeta Pendidikan Agama Kristen, pengajar, diaken, anggota di dalam badan atau komisi Pendidikan Agama Kristen, dan guru Sekolah Minggu. Ilmu pengetahuan tentang Pendidikan Agama Kristen yang dimiliki oleh kaum perempuan adalah anugerah Allah, yang sudah seharusnya untuk dikembangkan dan dipraktikkan di dalam gereja.
\end{abstract}

Kata Kunci: Perempuan, Pendidikan Agama Kristen Gereja 


\section{Pendahuluan}

Peranan wanita dalam pendidikan Kristen, berarti membahas dan mengamati bahkan menilai tindakan/kedudukan/fungsi yang dilakukan oleh seorang wanita dalam pendidikan tersebut. Peranan atau kiprah wanita di masa kini dapat dikatakan mengalami perkembangan yang cukup mengagumkan. Dinamika zaman memberikan kontribusi yang cukup besar bagi para wanita untuk memiliki andil dan peran yang besar. Dalam keseharian masyarakat, khususnya masyarakat Kristiani, tidak asing lagi mendengar seorang wanita, bekerja di kantor, mengajar, berkhotbah, bahkan menjadi seorang pemimpin.

Meski peranan wanita bagi sebagian orang tampak berkembang begitu cepat dan mengalami peningkatan yang pesat, namun bagi sebagian lainnya, kemajuan tersebut belum seperti yang diharapkan, khususnya di bidang keagamaan dalam hal ini adalah organisasi Kristen. Kemajuan dan keterlibatan dari peranan wanita yang belum terlalu signifikan dan belum menggembirakan tersebut, salah satunya yang terjadi di lembaga-lembaga pendidikan teologi.

\section{Tujuan dan Manfaat}

Untuk mengetahui sejauh mana pengaruh peranan perempuan dalam pendidikan Kristen dan dalam pelayanan terhadap pertumbuhan rohani. Pelayanan dan pendidikan yang diberikan kepada perempuan perlu mempersiapkan yang kreatif dan pelayanan yang diberikan harus mengikuti keteladanan Yesus dalam malakukan pelayanan dan pengajaran dengan tujuan akhir yaitu pertobatan, pembaharuan hidup serta kekuatan akan firman Allah dan dapat mempraktekkannya dalam kehidupan sehari-hari, sebab dapat bertumbuh dalam kasih, cinta pelayanan, dan perubahan karakter. 


\section{Pembahasan}

Kiprah atau peranan wanita yang semakin diakui dan berkembang serta semakin luas di masa kinidan Allah mempunyai rencana yang besar bagi umat-Nya, khususnya bagi kaum wanita. Kehidupan wanita yang pertama kali di bumi ini adalah menjadi kehidupan yang dilimpahi Allah dan Allah sangat mengasihi dan memperhatikannya, hal ini akan dibuktikan melalui Firman-Nya, baik itu yang dinyatakan dalam perjanjian Lama maupun Perjanjian Baru. Di sana tercantum beberapa nama wanita yang dipakai dan dikasihi-Nya. Sebagai bukti kasih-Nya juga kaum wanita diberi beberapa peran dan tanggung jawab.

Bahkan respon yang sering diberikan secara jujur berkeyakinan bahwa mereka tidak sanggup melaksanakan pelayanan tertentu bagi Allah. Akan tetapi anggapan yang demikian itu tidak benar, sebab keberadaan orang yang lemah bagaimanapun juga, pasti dapat berbuat sesuatu yang cocok dan sesuai dengan kemampuan yang dimilikinya. Pembedaan tanggung jawab antara laki-laki dengan perempuan nampak mulai timpang tatkala manusia jatuh ke dalam dosa ${ }^{1}$. Setidaknya, dalam melaksanakan tanggung jawabnya sudah terjadi pemilahan peran. Dalam Alkitab terlihat bahwa posisi laki-laki lebih dominan dibanding perempuan. Kendati demikian, dalam beberapa kasus, peranan perempuan tidak kalah penting dari laki-laki. Seperti yang ditampilkan tokoh-tokoh perempuan, seperti: Rahab, Rut, Debora, Ester, Maria, Lidya, dan lain-lain.

Tanggung jawab laki-laki dengan perempuan ini menjadi timpang ketika manusia jatuh ke dalam dosa. Dalam rangka pelaksanaan tanggung jawabnya sudah terjadi pemilahan peran yaitu laki-laki yang dibebani tanggung jawab sebagai pencari nafkah dengan mengelolah bumi (Kej. 3:17), sedang perempuan akan melahirkan dan mengasuh anak. Implikasinya secara praktis ialah laki-laki dianggap lebih kuat dan lebih penting daripada perempuan dalam segala hal. Laki-laki dominan di bidang publik, sementara perempuan didomestifikasi. Memang wanita diciptakan oleh Allah untuk jadi penolong dan tempat yang lebih baik untuk mulai menjadi penolong adalah di rumah tangganya sendiri. Ini adalah relevan dengan wanita saleh dan berbudi yang

${ }^{1}$ Jurnal Jabatan gerejawi dan peran perempuan dalam pelayanan gereja. 
dilukiskan dalam Amsal 31:27"Ia lah wanita yang mengawasi semua perbuatan dengan tangannya.

Jadi rasul Paulus sudah jelas mengajarkan bagi setiap wanita Kristen untuk segala zaman, supaya dewasa dalam imannya serta dalam kasus ini adalah wanita yang telah menikah "akan rajin mengatur rumah tangganya". Jadi dalam hal mengatur rumah tangga ini sangat dibutuhkan sikap yang positip, supaya terhindar dari rasa bosan dn jemu, karna melakukan pekerjaann yang rutin.Seorang wanita yang bijaksana akan menghindarkan diri dari kekliruan, ia menentukan prioritas yang tepat dengan membuat rencana, baik dalam jangka pendek maupun dalam jangka panjang. Sikap seperti ini dapat kita lihat dalam kehidupan wanita di dalam Amsal 31. Mengenai prinsip ini perempuan juga mempunyai tugas tertinggi yang dibebankan adalah memberitakan Injil atau anugrah Tuhan Yesus Kristus yang menyelamatkan orang-orang yang terhilang dan nyaris mati. Tugas pemberitaan tentang Injil bukanlah tugas sebagian anggota jemaat saja. Misalnya hanya tugas kaum laki-laki saja, atau kaum wanita saja, atau juga tugas kaum muda saja yang tenaganya masih berapi-api, akan tetapi pemberitaan Injil adalah tugas setiap orang percaya. Jadi setiap anggota jemaat harus memegang peranan ini. Pengertian setiap orang berarti mencakup serta melibtkan kaum wanita untuk pemberitaan tersebut.

Sahabat dan pengikut setia Yesus banyak yang perempuan seperti dicatat dalam Matius 27:55-56; Lukas 23:49. Tidak diragukan juga bahwa para perempuanlah orang-orang yang terakhir meninggalkan salib Yesus dan juga yang pertama melihat Yesus yang bangkit (Lukas 23:55). Di samping itu, semasa hidupNya perempuan selalu mengikuti Yesus dalam setiap perjalanan pelayananNya dan selalu membantu Yesus dan murdi-muridNya (Lukas 8:13). Jelas terlihat bahwa Yesus tidak melarang perempuan melakukan pelayanan bahkan Yesus juga menginginkan perempuan mendengarkan pengajaranNya dan melupakan semua kesibukan rutinitas perempuan demi pendengaran firman Allah serta laki-laki dan perempuan memiliki hak yang sama dalam pendengaran firman Allah.

Dalam hal yang sama perempuan masa kini menempatkan diri dalam pelayanan gereja ${ }^{2}$. Masih banyak jenis pelayanan yang bisa dilakukan para perempuan

\section{JURNAL DI ASKETISME DAN HARMONI KONTRIBUSI DISIPLIN DIRI BAGI PENGEMBANGAN PENDIDIKAN KRISTEN}


dalam gereja meskipun tidak menjabat sebagai pengkhotbah, pengajar dan pemimpin. Dalam sejarah gereja, latihan askese untuk menahan diri, mengosongkan diri, bahkan menyiksa diri merupakan hal yang wajib bagi seorang hamba Tuhan. Kegiatan ini bukan tradisi yang muncul begitu saja, atas dasar pemahaman pribadi terhadap Alkitab, namun praktik askese memang terdapat dalam Alkitab dan diperintahkan oleh Firman Tuhan. Pengendalian diri, Pengorbanan, Puasa, Pengosongan diri untuk kemuliaan Tuhan merupaan contoh dari pendidikan yang harus dialami oleh setiap anak-anak Tuhan.

Dan menjadi peneladanan berpadanan dengan konsep menyimak/mengamati dan menirukan sebagai salah satu aspek teori pendidikan agama Kristen (proses dan cara belajar anak dalam masa pertumbuhan $)^{3}$. Hampir semua ahli pendidikan sepakat bahwa keteladanan dan menirukan adalah alat yang paling ampuh untuk mengajarkan iman secara berulang-ulang. Keteladanan merupakan hal ideal yang dapat diupayakan oleh orang percaya, kendati tidak bersangkut-paut langsung dengan orang-orang percaya di dalam kenyataan. Artinya, keteladanan dapat memupuk pertumbuhan kepribadian dan karakter jika para murid telah memiliki modal dalam bentuk minat atau antusiasme. Sebagai salah satu aspek psikis yang penting, minat muncul dari dalam pikiran dan hati seseorang untuk mendorong hasrat dalam melakukan sesuatu (passion).

Dan perlu adanya minat yaitu "kecenderungan hati yang tinggi terhadap sesuatu, gairah, keinginan". Peneladanan perilaku akan semakin dikuatkan jika proses peniruan berlangsung secara berulang-ulang dan terus-menerus. Contohnya secara dinamis orang Toraja bisa bertumbuh dalam karakter luhur, sangup beradaptasi dan bertahan di tengah pengaruh identitas budaya baru ${ }^{4}$. Kendati ideologi tersebut berada dalam wilayah abstrak, namun diduga telah menjadi prinsip yang telah menuntun dinamika perkembanga peradaban mereka, aspek lain yang memukau adalah transmisi nilai budaya yang bersifat lisan. Dan dalam konsep teologi yang dominan atau umum

${ }^{3}$ Jurnal EXEMPLARY MENEMUKENALi KunCi PENDIDIKAN IMAN BAGI ANAK DALAm Keluarga dan PEMBELAJARAN Agama Di SEKOlaH

${ }^{4}$ Jurnal teologi dan pendidikan kontekstual 
menjadi warna teologis di kitab Rut yaitu : pemeliharaan Tuhan, kasih setia (khesed), Penebus, kemisteriusan pekerjaan Tuhan dalam kehidupan umat-Nya, Daud dan leluhurnya ${ }^{5}$. 


\section{Kesimpulan dan Saran}

Di jaman yang sudah maju ini sepak terjang kaum wanita sudah sangat berbeda di mana perannanya masih sering dibatasi. Kondisi ini membuat sebagian kaum wanita kurang giat berjuang untuk menampakan dan meningkatkan perannya. Sebagai kaum wanita Kristen harus memiliki sikap dan mental yang kuat dalam memahami perannanya baik sebagai istri yang harus mengasihi dan tunduk kepada suami serta mendidik anak-anak, juga menyadari perananya di dalam gereja. Tetapi harus di mengerti bawhwa wanita kristen yang melibatkan dalam berbagai kegiatan di gereja harus bisa membagi dan mengatur waktu dengan tepat supaya ada keseimbangan, untuk berbagai kegiatan di dalam kehidupannya, sehingga bisa memberi perhatian yang cukup, kalau tidak maka kaum wanita tidak bisa melakukan pekerjaan yang baik untuk Tuhan. 


\section{Daftar Pustaka}

Jurnal Jabatan gerejawi dan peran perempuan dalam pelayanan gereja.

JURNAL DI ASKETISME DAN HARMONI KONTRIBUSI DISIPLIN DIRI BAGI PENGEMBANGAN PENDIDIKAN KRISTEN

Jurnal EXEMPLARY MENEMUKENALi KunCi PENDIDIKAN IMAN BAGI ANAK DALAM Keluarga dan Pembelajaran Agama di SEKOlah

Jurnal teologi dan pendidikan kontekstual

Jurnal KAMASEAN: JURNAL TEOLOGI KRISTEN 